\title{
Research on International Trade based on Financing Risk Management of Commercial Banks
}

\author{
Ying Zheng, Baojing Zhou, Feng Wu
}

Shandong Vocational College of Science \& Technology, Weifang, Shandong, 261041

Keywords: Commercial Bank, Risk Management, International Trade

\begin{abstract}
With the acceleration of the global integration process and the prosperity of international trade, the proportion of national trade finance business in China's commercial banks is also growing. At present, developed economies are gradually emerging from the impact of the previous financial crisis. In the face of increasingly fierce market competition, domestic banks are inevitably exposed to the shortcomings of risk management in the process of handling international trade financing for import and export enterprises. The international trade finance business is also a double-edged sword for China's commercial banks. While giving banks a more comprehensive and broader source of income than traditional loan business, the hidden risks are also lower than other businesses. In recent years, China's economic growth has gradually slowed down, and the growth rate of international trade has decreased slightly compared with that a few years ago. Some import and export enterprises that are weak against market risks have also been affected. The incident of financial chain break caused by poor management is also occasionally, the frequency of fraud and illegal arbitrage caused by the authenticity of international trade financing at the bank level has also increased, and international trade financing disputes are much higher than that in the past. Therefore, in the current economic environment, how to clearly identify the risks of international trade financing, strengthen the risk management of international trade financing, and reduce the risk loss caused by international trade financing risk events to China's commercial banks is also urgent.
\end{abstract}

\section{Introduction}

In the 1990s, the international trade financing of China's commercial banks gradually developed. Especially after China's accession to WT0, through frequent trade with countries around the world in various fields, the total volume of imports and exports increased year after year. With the gradual acceleration of international trade, in order to adapt International conventions, the importance of commercial bank international trade financing is also gradually reflected. In the international context of further opening up in the financial sector, the threat of foreign banks in China's domestic commercial banks has gradually increased. With regard to the accumulated experience of foreign banks over the past 100 years, the market competition and survival pressure faced by domestic commercial banks in China have become increasingly fierce. The original commercial bank financing business varieties have gradually failed to meet the current international trade demand. Domestic commercial banks are In this case, innovation in international trade finance business has also been widely carried out. With the upward trend in international trade and the rapid development of international trade finance business, various risks have also gathered.

\section{Analysis of the Factors Affecting the Risk of International Trade Finance Business of Commercial Banks}

At present, the internal factors that cause the risk of commercial bank international trade financing are mainly the following three forms of expression. A lack of awareness of risk management is extensive. Since commercial banks are dealing with international trade financing, they tend to think that the financing risk is low because of the self-compensation of trade finance business. In particular, the domestic trade finance business is directly linked to the international settlement volume. In recent years, the bank's international settlement and other business indicators. 
The continuous rise of this has led commercial banks to pay too much attention to the amount of international settlements and trade financing when handling international trade financing, and ignore the quality of financing for the long-term international business volume. International trade financing involves multiple links. Due to the lack of understanding of risks, as the risk is gradually increased, once there is an error in a certain link, it will cause financial losses to the bank's financing risks.

Second, the internal control management is imperfect, and there is a lack of checks and balances on risk management. At present, due to the late start of international trade financing in China, most banks did not have sufficient risk monitoring when handling international trade financing business, and failed to establish an effective internal control management system. Although with the development of the times, banks have established operational procedures and management systems for international trade financing, international trade financing is often time-sensitive, banks have simple procedures in the financing approval process, and international trade financing operations are approved. By a single department audit, failure to achieve separation of loans, lack of checks and balances on risk management, and no sound risk identification mechanism, resulting in risk warnings can not be issued in a timely and effective manner, risk mitigation means is relatively simple, in the case of risk signs, often can not effectively resolve the risk, and thus cause losses to the bank.

Third, the lack of experience of operators and the lack of professional talents. There are many links in international trade, which puts high demands on the quality of financing business investigators and examiners. At present, the investigation and approval of the international business of each bank is mostly transferred from the former company's business staff or new to the bank. Academic staff, for international trade financing, most international practices, clause interpretation, laws and regulations involve foreign languages, and related financing business requires a lot of financing business experience, these two reasons have caused professionalism in international trade financing business The lack of talent makes it difficult to ensure that all aspects of business risk are taken into account. At the same time, due to the wide-ranging knowledge level involved in international business, the employees of the bank risk management department cannot learn from the experience of dealing with traditional financing business risk events when dealing with international business risk events, thus affecting the bank's consolidation interests.

\section{Dealing with the risk of international trade financing business of commercial banks}

Commercial banks have the following control measures for different links in the issuance of letters of credit. The first trial link: The enterprise that first opened the letter of credit must have the right to import and export, and there is no bad financing record in the import and export payment list of the SAFE. Secondly, it is necessary to examine whether the contract provided by the enterprise is true and effective, and the amount of the letter of credit and the payment term need to meet the requirements of normal trade financing. At the same time, the company needs to submit the basic documents such as the application for the issuance, the general agreement, the import contract and the business license.

Credit review: Commercial banks will clearly review the contents of the company, review the company's basic conditions, financial status, production and operation, financing and credit status and industry market environment to ensure that the company has sufficient credit. Secondly, it is necessary to implement the guarantee measures, the legal validity of the partial guarantee of the margin and the margin difference, and after signing the audit and confirming the correctness, the guarantee contract will be signed. Since the exchange rate is involved, it is necessary to consider the exchange rate fluctuation to increase the deposit as appropriate. The deposit is charged at the maximum amount of the deposit. Technical review: The terms of the letter of credit must be confirmed and regulated by the company, and the words must not be ambiguous. There must be no clauses and soft terms that are unfavourable to commercial banks. A forward letter of credit issued from the acceptance date to the payment date of more than 365 days shall be reported to the local foreign exchange administration for approval. In case of extension of validity period, increase in 
amount, extension of payment period, etc., the communication certificate will be re-examined.

When the commercial bank handles the export business, it takes the accounts receivable as the first source, so the risk control adopts the overall control method, which is not carried out in the import financing business. The key points of the risk control are as follows: The corporate trade background needs to be true and effective. It is necessary to understand the historical cooperation between the import and export parties and whether there are disputes over trade disputes and litigation. Whether there is any pledge, transfer or opposition registration under the line item. Implement the borrower's production and operation status, market competitiveness, historical performance record, performance capability and sales record. The credit rating is in principle A grade (including). Strictly review whether the trade background of connected transactions is true, and the rationality and fairness of the pricing of goods under the order. Pay attention to whether the payment terms, methods and payment arrangements of the order are in line with the industry trading practice, whether the pricing of the goods under the order is reasonable, and whether the restrictive clauses in the order affect the recovery of the financing of the commercial bank. Examine the variety, quantity and specifications of raw materials purchased by exporters, whether the production requirements under the single item are consistent, and whether the purchase price of raw materials is reasonable. At the same time, customers who handle export order financing in commercial banks must go through the export of poor financing or export settlement services (including export collection or export TT collection services) in the subsequent steps of the order. The handling bank shall continue to track the progress of the borrower's performance, and deliver and deliver the goods strictly in accordance with the deadlines required by the order.

In the actual operation, there have been such cases. Y City decided to substantially reduce its credit according to the analysis of the financial status of A aquatic companies in J Bank. Due to the excessive credit quota, the A company's capital chain was broken and it was unable to repay other local businesses on time. When the bank expires international trade financing, since the local fishery enterprises guarantee each other, when the A company fails to repay the financing principal and interest on time, according to the guarantee agreement, it must be repaid by other aquatic enterprises on its behalf, resulting in financial problems in the entire aquatic industry of Y City. At the same time, $\mathrm{J}$ Bank is one of the four major state-owned banks. Due to the compression of the credit granted to A's aquatic products enterprises, the risk of possible losses has not been reduced. Other joint-stock banks have simultaneously compressed the credits of other enterprises in the entire aquaculture industry, resulting in a snowball effect, most of which are normal operations. The aquatic enterprises caused adverse effects and once threatened the safety of the entire industry. Later, the Y municipal government came forward to unite with a number of local banks and financial institutions, and one of the fund companies guaranteed each enterprise. The credit commitments of various aquaculture enterprises have temporarily eased the problem of liquidity of the local fisheries industry, but the impact has not been remedied. Although the banks have promised not to compress the credit, their requirements for international trade financing approval and guarantee measures are more stringent. Affected by this, the import and export volume of the fishery industry in Y City has dropped drastically. The aquatic industry has not recovered its original scale after 3 years of this incident. Therefore, banks should follow the principle of not expanding risks when compressing corporate credits. Problem, avoid recurring such problems. However, if the company has obvious unsustainable risks, the bank should still take decisive measures to recover the financing funds in a timely manner through legal means to avoid causing bank losses.

\section{Conclusion}

With the continuous growth of the international trade market, the proportion of international trade financing business in China's commercial banks is also growing. The development of international trade financing business not only brings new profit growth points to China's commercial banks, but also brings new challenges to China's commercial banks in risk management. While expanding the market share of international business, China's commercial banks can not only focus on revenue, improve risk prevention awareness, and strengthen risk control is also the top 
priority in bank management. The importance of a sound risk prevention and control management system for the comprehensive development of China's commercial banks is self-evident. The key to the risk management of China's commercial banks' national trade finance lies not only in their emphasis on relevant risks, but also on the effective implementation of relevant risk management plans.

\section{References}

[1] Ba Shusong. Problems and Suggestions on the Implementation of Basel New Capital Accord by Small and Medium-sized Banks in China [J]. Finance and Economy, 2011(1): 4-7

[2] Huang Haining. Innovative trends in international trade finance business [J]. New Finance, 2006 (11): $36-40$

[3] Huang Zhiling. Modern credit risk quantitative measurement and management research [J]. Knowledge Economy, 2017 (10): 80-82

[4] Li Jie. Commodity import trade risk prevention [J]. China Foreign Exchange, 2014(18): 34-35

[5] Li Xuemei. Analysis on the Risk Management of International Trade Finance of China's Commercial Banks [J]. Journal of Harbin Vocational and Technical College, 2016(1): 138-140 